\title{
Enhanced thermal stability of laccase immobilized on monolayer- modified nanoporous Au
}

\section{$\operatorname{AUTHOR}(\mathrm{S})$ :}

Hakamada, Masataka; Takahashi, Masaki; Mabuchi, Mamoru

\section{CITATION:}

Hakamada, Masataka ...[et al]. Enhanced thermal stability of laccase immobilized on monolayer-modified nanoporous Au. Materials Letters 2012, 66(1): 4-6

\section{ISSUE DATE:}

2012-01-01

URL:

http://hdl.handle.net/2433/237627

\section{RIGHT:}

(c) 2011. This manuscript version is made available under the CC-BY-NC-ND 4.0 license

http://creativecommons.org/licenses/by-nc-nd/4.0/; The full-text file will be made open to the public on 1 January 2014 in accordance with publisher's 'Terms and Conditions for Self-Archiving'.; This is not the published version. Please cite only the published version.; この論文は出版社版でありません。引用の際には出版社版をご確認ご利用ください。 


\title{
Enhanced thermal stability of laccase immobilized on monolayer-modified nanoporous Au
}

\author{
Masataka Hakamada*, Masaki Takahashi and Mamoru Mabuchi \\ Department of Energy Science and Technology, Graduate School of Energy Science, Kyoto \\ University, Yoshidahonmachi, Sakyo, Kyoto 606-8501, Japan \\ * Corresponding author. Tel: +81-75-753-5427; Fax: +81-75-753-5428; E-mail: \\ hakamada.masataka.3x@kyoto-u.ac.jp.
}

\begin{abstract}
Nanoporous Au was fabricated by the dealloying of Au-Ag alloy in nitric acid, and was modified with a self-assembled monolayer (SAM) of 4-aminothiophenol, for the enhancement of high-temperature activity of immobilized laccase. Immobilized laccase exhibited much higher activity than that of free laccase at $>45^{\circ} \mathrm{C}$. SAM surface modification greatly improved the thermal stability and reusability of immobilized laccase. For example, little degradation in laccase activity when immobilized on SAM-modified nanoporous Au was observed after two hours incubation at $50^{\circ} \mathrm{C}$. This suggested the nanoporous structure and SAM synergistically prevented the conformational change of laccase, and resulted in the enhancement of high-temperature activity.

Keywords: self-assembled monolayer; bioelectrode; nanoporous Au; thermal stability
\end{abstract}

\section{Introduction}

Laccase is a useful enzyme capable of oxidizing a large number of organic and inorganic substrates, with the concomitant reduction of molecular oxygen to water [1]. It has recent significant attention regarding potential applications in the fields of biosensors and biofuel cells [2-4]. 
Immobilization of laccase on an appropriate support is a promising method for the manufacture of bioelectrodes [5-8], due to the straightforward separation of the enzyme from its reaction mixture, and also the reusability and increased stability of the immobilized enzyme. The use of nanostructured materials for enzyme support has received broad attention in recent years. Au nanoparticles have been widely used due to their biocompatibility, high specific surface area and catalytic activity $[9,10]$.

Nanoporous metals with open-cellular structures of nanosized ligaments and pores are also candidates for enzyme supports [11-13]. Nanoporous Au (np-Au) can be readily fabricated by the dealloying of Ag-Au alloys [14]. Self-assembled monolayers (SAMs) on Au surfaces are also often used for improving enzyme activity $[2,15]$. In the current study, the effect of a SAM on the activity of laccase-immobilized np-Au has been elucidated.

\section{Materials and Methods}

Commercially available $\mathrm{Au}$ (>99.9 mass\%) and Ag (>99.9 mass\%) ingots were melted together by arc melting under an $\mathrm{Ar}$ atmosphere to prepare precursor $\mathrm{Au}_{0.35} \mathrm{Ag}_{0.65}$ alloy ingot. After homogenization at $1173 \mathrm{~K}$ for $24 \mathrm{~h}$ under an Ar atmosphere and subsequent cold rolling to a thickness of $0.2 \mathrm{~mm}$, np-Au was fabricated by the immersion of the alloy in 70 mass\% $\mathrm{HNO}_{3}$ for 8 days at room temperature. Figure 1 shows a scanning electron microscopy (SEM) image of the obtained np-Au, from which an average pore size of $40 \mathrm{~nm}$ was apparent (pore size was determined as the distance between adjacent ligaments).

Monolayers of 4-aminothiophenol (4-ATP) [2] were then self-assembled on several np-Au samples. Samples were soaked in $20 \mathrm{mM}$ ethanol solutions of 4 -ATP for $65 \mathrm{~h}$ at room temperature under ambient atmosphere. Following immersion, samples were thoroughly rinsed with ethanol to remove excessive 4-ATP. 


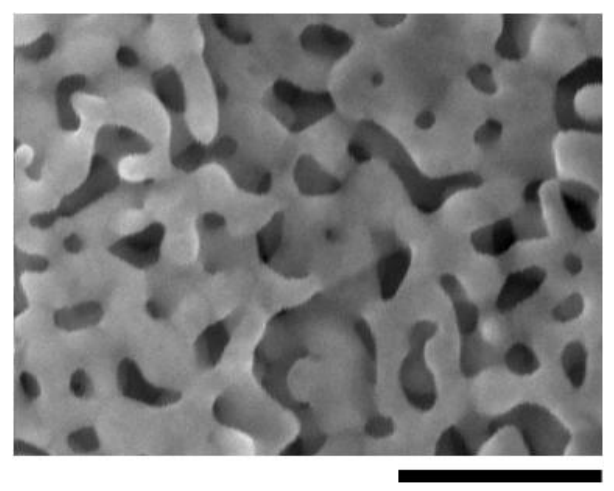

$200 \mathrm{~nm}$

Figure 1. SEM image of the nanoporous Au.

To immobilize laccase, np-Au samples (with and without a 4-ATP SAM) were stored quiescently in $2 \mathrm{~mL}$ of $7 \mathrm{mg} / \mathrm{mL}$ laccase (Trametes versicolor from Sigma) solution (diluted by $0.1 \mathrm{M}$ citrate- $0.2 \mathrm{M}$ phosphate buffer solution, $\mathrm{pH}=5.0$ ) at $4{ }^{\circ} \mathrm{C}$ for $24 \mathrm{~h}$. np-Au samples were then rinsed five times with $10 \mathrm{~mL}$ of buffer solution to remove any excess or only weakly adsorbed enzyme.

The activities of free and immobilized laccase were spectrophotometrically determined on the basis of the absorbance change at $470 \mathrm{~nm}$. An appropriate amount of laccase $(5 \mu \mathrm{L}$ of free laccase solution or $20 \mathrm{mg}$ of laccase-immobilized $\mathrm{np}$-Au in fragments) was stirred with $3 \mathrm{~mL}$ of buffer solution and $300 \mu \mathrm{L}$ of $10 \mathrm{mM}$ 2,6-dimethoxyphenol (DMP) [12,13].

Activity assays were carried out over the temperature range $35-75^{\circ} \mathrm{C}$ to determine thermal stability. After a five min reaction, the absorbance of the supernatant was measured using a UV-vis. spectrophotometer (UV-3100PC, Shimadzu Corporation, Kyoto). The effect of incubation time was examined by incubating free laccase and laccase-immobilized np-Au in buffer solution $(\mathrm{pH}=5.0)$ at $50^{\circ} \mathrm{C}$. At given time intervals, $5 \mu \mathrm{L}$ of free enzyme solution or $20 \mathrm{mg}$ of laccase-immobilized np-Au was removed and left to stand in the buffer solution for $1 \mathrm{~h}$ at room temperature. The residual activity was 
then assayed at $35^{\circ} \mathrm{C}$ by the methods described above.

To test reusability, laccase-immobilized np-Au (25 mg, in fragments) samples were removed from the reaction solution ( $3 \mathrm{~mL}$ buffer solution and $300 \mu \mathrm{L}$ of $10 \mathrm{mM}$ 2,6-DMP) after a ten min reaction at $35^{\circ} \mathrm{C}$, and were rinsed three times with the buffer solution. Laccase-immobilized np-Au was then immersed in a fresh reaction solution for the next cycle $\left(10\right.$-min reaction at $\left.35^{\circ} \mathrm{C}\right)$. Following reaction, laccase-immobilized np-Au was removed, and the reacted solution was immediately transferred to a cuvette for absorbance measurement.

\section{Results and Discussion}

Activity temperature dependence of free and immobilized laccase is shown in Figure 2. Laccase immobilized on np-Au exhibited clear increased activity with respect to free laccase, at temperatures $>45^{\circ} \mathrm{C}$. The optimum temperature of laccase-immobilized np-Au $\left(45^{\circ} \mathrm{C}\right)$ was higher than that of free laccase $\left(35^{\circ} \mathrm{C}\right)$. The optimum temperature of SAM-decorated np-Au $\left(55^{\circ} \mathrm{C}\right)$ was also slightly higher than that of nanoporous samples without decoration.

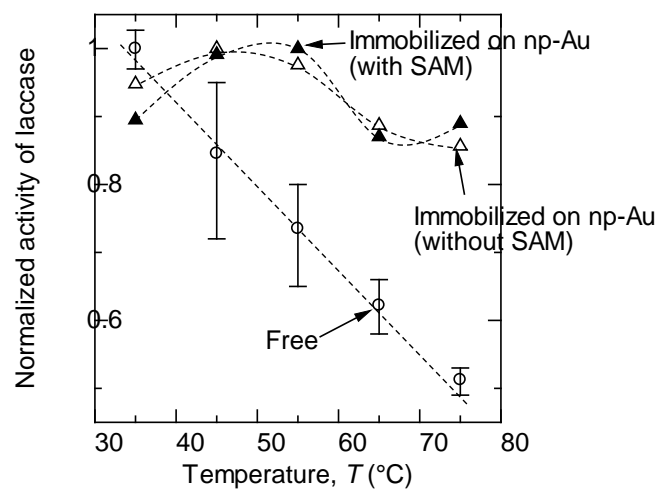

Figure 2. Relationship between temperature and activity of free and immobilized laccase.

To aid comparison, activities were normalized to the maximum activity for each sample. Error bar shows maxima and minima of the data, whereas error in the data for immobilized laccase is too small to be shown. 
The effect of incubation time at $50^{\circ} \mathrm{C}$ on the activity of free and immobilized laccase is shown in Figure 3 (a). The activity of free laccase and laccase-immobilized np-Au without SAMs was found to decrease with increasing incubation time. After 30 min, free laccase had lost approximately $70 \%$ of its activity, compared with laccase-immobilized $\mathrm{np}-\mathrm{Au}$ in the absence of a SAM which had lost only $20 \%$ of its activity. Furthermore, laccase-immobilized np-Au with SAM showed far higher thermal stability than the other samples. Little degradation in activity (10\%) was observed after a $2 \mathrm{~h}$ incubation at $50^{\circ} \mathrm{C}$.

(a)

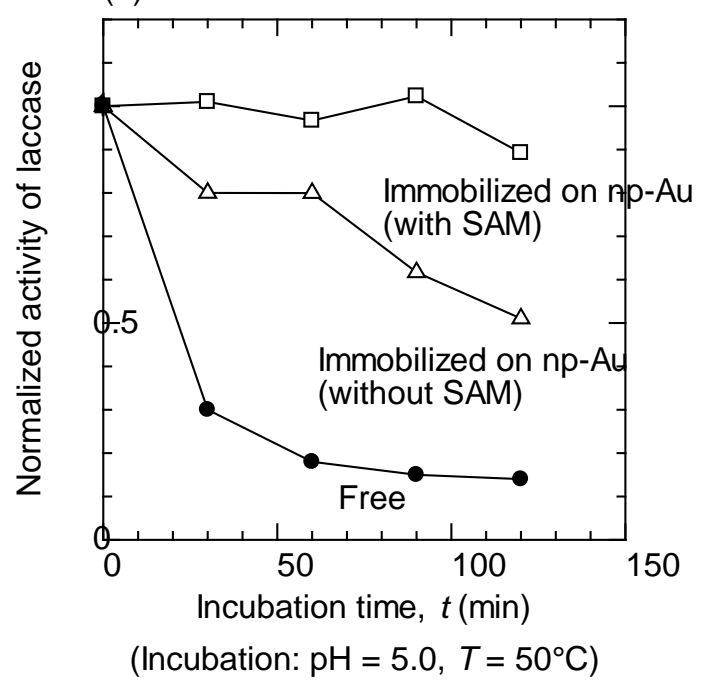

(b) Immobilized on np-Au

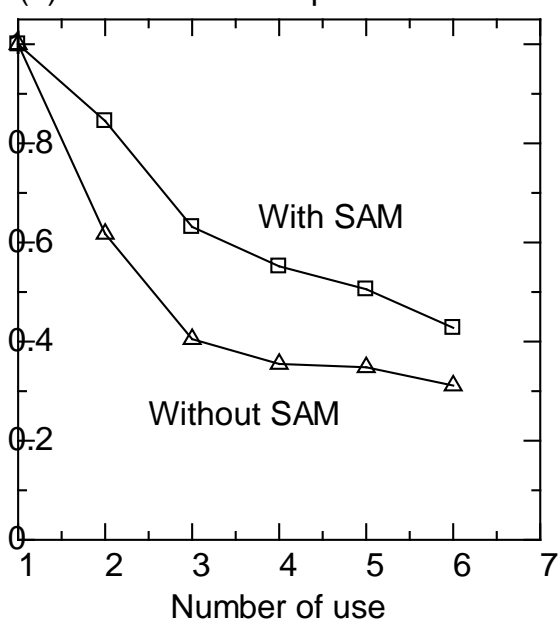

Figure 3. Effect of (a) incubation time and (b) reuse number, on enzyme activity for free and immobilized laccase. Activities shown on the vertical axes were normalized to initial activity.

The residue activity of immobilized laccase after repeated use at $35^{\circ} \mathrm{C}$ and at $\mathrm{pH}=$ 5.0 is shown in Figure 3 (b). Repeated use decreased the activity of the immobilized enzyme, but $30 \%$ of the initial activity was still retained after 6 cycles. During repeated use, SAM-decorated np-Au exhibited higher residual activity to the enzyme than that of 
undecorated np-Au. These results indicated that laccase-immobilized SAM-decorated np-Au had a higher stability and practical reusability than np-Au in the absence of the SAM.

The above results demonstrated that the np-Au support had a protecting effect at high temperatures in which the enzyme would usually deactivate. np-Au functionalized with SAM appeared to bind to the immobilized enzyme more strongly and increase the enzyme's stability. The immobilization of laccase on SAM-decorated np-Au was thought to have preserved the tertiary structure of the enzyme.

Immobilized enzymes have frequently been shown to exhibit higher thermal stability than the corresponding free enzyme, because of the reduction in conformational flexibility $[4,16]$. The enhancing effect of SAMs on the function of adsorbed enzymes has been repeatedly demonstrated [2,3], and the improvement in SAM stability on defective Au surfaces has been also reported [17]. Nanoporous metals possess lattice disorder including changes in lattice spacing and atomic vacancy at the ligament surface [18]. As a consequence, SAMs by themselves exhibited a stabilization of the np-Au. The synergy between nanoporous structure and the enhanced stability and promoting effect of the SAM resulted in an increased thermal stability of laccase, which protected the enzyme from thermal-induced conformational changes.

\section{Conclusions}

The enzymatic properties of laccase-immobilized np-Au have been examined. SAMs on np-Au synergistically enhanced the activity of adsorbed laccase. SAM-modified nanoporous metals are attractive substrates for enzymatic-based bio-device applications.

\section{Acknowledgements}

This study was supported by JSPS KAKENHI (22656155). 


\section{References}

[1] Yaropolov AI, Skorobogat'ko OV, Vartanov SS, Varfolomeyev SD. Laccase Properties, catalytic mechanism, and applicability. Appl Biochem Biotech 1994;49:257-80.

[2] Gupta G, Rajendran V, Atanassov P. Laccase biosensor on monolayer-modified gold electrode. Electroanalysis 2003;20:1577-83.

[3] Mena ML, Carralero V, González-Cortés A, Yáñez-Sedeño P, Pingarrón JM. Laccase biosensor based on N-succinimidyl-3-thiopropionate-functionalized gold electrodes. Electroanalysis 2005;23:2147-55.

[4] Deng L, Wang F, Chen H, Shang L, Wang L, Wang T, Dong S. A biofuel cell with enhanced performance by multilayer biocatalyst immobilized on highly ordered macroporous electrode. Biosens Bioelecton 2008;24:329-33.

[5] Johnson DL, Thompson JL, Brinkmann SM, Schller KA, Martin LL. Electrochemical characterization of purified Rhus Vernicifera laccase: voltammetric evidence for a sequential four-electron transfer. Biochemistry 2003;42:10229-37.

[6] Trudeau F, Daigle F, Leech D. Reagentless mediated laccase electrode for the detection of enzyme modulators. Anal Chem 1997;69:882-6.

[7] ElKaoutit M, Naranjo-Rodriguez I, Temasamani KR, de la Vega MD, de Cisneros JL. Dual laccase-tyrosinase based sonogel-carbon biosensor for monitoring polyphenols in beers. J Agric Food Chem 2007;55:8011-8.

[8] Fei J, Song HK, Palmore GTR. A biopolymer composite that catalyzes the reduction of oxygen to water. Chem Mater 2007;19:1565-70.

[9] Guo S, Wang E. Synthesis and electrochemical applications of gold nanoparticles. Anal Chim Acta 2007;598:181-92.

[10] Daniel MC, Astruc D. Gold nanoparticles: assembly, supramolecular chemistry, 
quantum-size-related properties, and applications toward biology, catalysis, and nanotechnology. Chem Rev 2004;104:293-346.

[11] Shulga OV, Jefferson K, Khan AR, D’Souza VT, Liu J, Demchenko AV, Stine KJ. Preparation and characterization of porous gold and its application as a platform for immobilization of acetylcholine esterase. Chem Mater 2007;19:3902-11.

[12] Qiu H, Xu C, Huang X, Ding Y, Qu Y, Gao P. Adsorption of laccase on the surface of nanoporous gold and the direct electron transfer between them. J Phys Chem C 2008;112:14781-5.

[13] Qiu H, Xu C, Huang X, Ding Y, Qu Y, Gao P. Immobilization of laccase on nanoporous gold: comparative studies on the immobilization strategies and the particle size effects. J Phys Chem C 2009;113:2521-5.

[14] Forty AJ, Durkin P. A micromorphological study of the dissolution of silver-gold alloys in nitric acid. Philos Mag A 1980;42:295-318.

[15] Pita M, Shleev S, Ruzgas T, Fernández VM, Yaropolov AI, Gorton L. Direct heterogeneous electron transfer reactions of fungal laccases at bare and thiol-modified gold electrodes. Electrochem Comm 2006;8:747-53.

[16] Hudson S, Cooney J, Magner E. Proteins in mesoporous silicates. Angew Chem Int Ed 2008;47:8582-94.

[17] Cortés E, Rubert AA, Benitez G, Carro P, Vela ME, Salvarezza RC. Enhanced stability of thiolate self-assembled monolayers (SAMs) on nanostructured gold substrates. Langmuir 2009;25:5661-6.

[18] Hakamada M, Nakano H, Furukawa T, Takahashi M, Mabuchi M. Hydrogen storage properties of nanoporous palladium fabricated by dealloying. J Phys Chem C 2010;114:868-73. 